
УЧНІВ ПОЧАТКОВОЇ ШКОЛИ В ПРОЦЕСІ НАВЧАННЯ ІНОЗЕМНОЇ МОВИ: ІНТЕРПРЕТУВАННЯ РЕЗУЛЬТАТІВ АНАЛІЗУ ЧИННИХ НАВЧАЛЬНИХ ПРОГРАМ

\title{
CONTINUITY OF FORMATION OF KEY COMPETENCES OF ELEMENTARY SCHOOL STUDENTS IN THE PROCESS OF LEARNING A FOREIGN LANGUAGE: INTERPRETATION OF THE RESULTS OF THE ANALYSIS OF THE CURRENT CURRICULUM
}

У статті на основі аналізу змісту чинної навчальної програми з іноземних мов та узагальнення його результатів визначено наступність формування визначених ключових компетентностей учнів початкової школи відповідно до загальних характеристик ситуативного спілкування. Критеріями аналізу стали тематичний, тексичний, функиійний. Особливу увагу приділено проблемі врахування в освітньому процесі психофізіологічних особливостей учнів початкових класів. Доведено, що формування ключових компетентностей учнів початкових класів у проиесі навчання іноземної мови має здійснюватися комплексно, передусім через добір ситуативних завдань, які спонукають до засвоєння мовного матеріалу, соиіокультурних реалій, а також сприяють розщиренню комунікативного й соціального досвіду учнів.

Ключові слова: ключові компетентності учнів початкових класів, навчальна програма, наступність, психобізіологічні особливості учнів початкових класів.

Сучасні глобалізаційні процеси, інтегрування України до світового освітнього та інформаційного простору, динамічні темпи розвитку інформаційно-комунікаційних технологій зумовлюють актуальність і важливість вивчення іноземної мови як засобу міжособистісного і міжкультурного спілкування. Це й спричинило підвищення уваги до навчання іноземної мови, у тому числі здобувачів початкової освіти. 3 огляду на те, що провідним в системі освіти України визнано компетентнісний підхід, у межах кожної навчальної дисципліни виокремлено важливий напрям розв'язання освітніх завдань, спрямований на формування, розвиток і вдосконалення ключових компетентностей учнів.

Опрацювання спеціальних наукових джерел засвідчує, що навчання іноземної мови

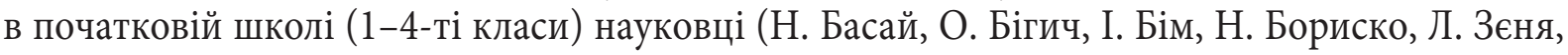
І. Зимня, Л. Калініна, Р. Мільруд, С. Ніколаєва, О. Пасічник, Ю. Пассов, Т. Полонська, В. Редько та ін.) розглядають як “перший ступінь, що різнобічно співвідноситься з освітніми галузями основної та старшої школи. Це й зумовлює його цільове спрямування, змістове наповнення, неперервність і наступність у всьому шкільному курсі" [6, с. 145]. Від продуктивності навчання іноземної мови в 1-4-х класах значною мірою залежить якість подальшої мовної освіти, оскільки "саме в початкових класах, де учні вперше ознайомлюються з культурою і мовою іншого народу, формується їхнє ставлення до навчального предмета “іноземна мова”, закладаються психолінгвістичні основи іншомовної комунікативної компетентності, необхідні та достатні для подальшого її розвитку й удосконалення [6, с. 127].

Meта статmi - на основі аналізу змісту чинної навчальної програми з іноземних мов та узагальнення його результатів продемонструвати наступність формування визначених

(c) Ігор Горошкін, 2019 
ключових компетентностей учнів початкової школи відповідно до загальних характеристик ситуативного спілкування, як-от: тематика, лексичний діапазон, мовленнєві функції.

Нормативними документами визначено 10 ключових компетентностей, що мають бути сформовані в здобувачів освіти. Головною метою навчання іноземної мови в початкових класах $\epsilon$ “формування комунікативної компетентності учня молодшого шкільного віку на доступному для нього рівні в основних видах мовленнєвої діяльності: аудіюванні, говорінні, читанні й письмі. Звичайно, йдеться про формування елементарної комунікативної компетентності, яка розуміється як здатність і готовність учня здійснювати міжособистісне і міжкультурне спілкування іноземною мовою в усній і письмовій формах у межах найтиповіших сфер і тем спілкування, доступних для нього" [6, с. 134]. У цьому контексті нам видається логічним говорити про відносну, або елементарну, сформованість ключових компетентностей учнів початкових класів, оскільки в цей період учні тільки починають системно опановувати іноземну мову. Окреслена мета може бути успішно реалізованою за умови врахування в освітньому процесі психофізіологічних особливостей учнів початкових класів.

Результати аналізу спеціальної літератури засвідчили, що проблему залежності ефективності навчання іноземних мов учнів початкових класів від їхніх вікових особливостей частково висвітлено в наукових працях як українських (О. Коломінова, С. Ніколаєва, В. Редько, С. Роман та ін.), так і зарубіжних (Б. Беляєв, І. Зимня, О. Леонтьєв та ін.) дослідників. Утім, у контексті викликів сьогодення потребує додаткового й ретельного вивчення проблема вікових особливостей молодших школярів під кутом зору їхніх потенційних можливостей оволодіння компетентнісно орієнтованим змістом навчання іноземних мов $[6 ; 8 ; 9]$.

Психологи стверджують, що в молодшому шкільному віці відбувається формування провідної для цього вікового періоду навчальної діяльності, необхідних умінь і навичок, “психологічна перебудова, що потребує від суб’єктів освітнього процесу не тільки значного розумового напруження, а й більшої фізичної витривалості” [2], триває соціально-особистісний розвиток дитини. Означений віковий період характеризується появою системи уявлень про інших людей, довкілля, морально-етичні норми, на основі яких будуються взаємини з однолітками і дорослими, відбувається адаптація в мікросоціумі. Нам імпонує думка, що "Кожен рік перебування у школі дітей молодшого шкільного віку характеризується значними якісними трансформаціями в різних сферах їхньої розумової діяльності. Вони по-різному відбиваються в пам'яті, поведінці, мисленні, мовленні, мотивах, діях, інтересах, ставленнях, оцінках тощо. У зв'язку з цим дидактично недоцільно і методично невиправдано узагальнювати методи, форми, способи, види навчальної діяльності, що можуть бути типовими для всіх учнів початкової школи. Кожний наступний рік просування дітей у своєму розвиткові в межах 1-4 класів зумовлює пошуки різних дидактичних і методичних підходів до реалізації змісту навчання, у тому числі й до використання методів, форм і способів оволодіння ним відповідно до певної педагогічної парадигми” [6, с. 181]. А це означає, що визначені в чинній програмі ключові компетентності формуються в учнів 1-4-х класів у процесі навчання іноземних мов різною мірою.

Аналіз змісту чинної навчальної програми з іноземних мов та узагальнення його результатів дають нам змогу проілюструвати послідовність і наступність формування ключових компетентностей учнів початкових класів. Критеріями аналізу було визначено тематичний, лексичний, функційний. Тематичний критерій відображав потенційні можливості тем ситуативного спілкування для формування ключових компетентностей учнів початкової школи. Лексичний - визначав відповідність лексики, яку засвоюють учні початкових класів для формування ключових компетентностей. Функційний критерій дав змогу побачити можливість формування означених компетентностей через низку мовленнєвих функцій, які опановують учні 1-4-х класів. 
Таблиия 1

Формування ключових компетентностей на уроках іноземної мови в учнів першого класу

\begin{tabular}{|c|c|c|c|c|c|c|}
\hline \multicolumn{7}{|c|}{1 клас } \\
\hline & \multicolumn{6}{|c|}{ Тематика ситуативного спілкування } \\
\hline $\begin{array}{c}\text { Ключові } \\
\text { компетентності }\end{array}$ & $\begin{array}{c}\text { Я, моя } \\
\text { родина і } \\
\text { друзі }\end{array}$ & Дозвілля & Природа & Свята & $\begin{array}{l}\text { Харчу- } \\
\text { вання }\end{array}$ & Школа \\
\hline $\begin{array}{c}\text { Спілкування } \\
\text { державною (рідною) } \\
\text { мовою } \\
\end{array}$ & \multicolumn{6}{|c|}{ Формується частково } \\
\hline $\begin{array}{c}\text { Спілкування } \\
\text { іноземними мовами }\end{array}$ & \multicolumn{6}{|c|}{ Формується } \\
\hline $\begin{array}{c}\text { Математична } \\
\text { компетентність }\end{array}$ & $\begin{array}{c}\text { Форму- } \\
\text { ється } \\
\text { частково }\end{array}$ & \multicolumn{5}{|c|}{ Формується ситуативно } \\
\hline $\begin{array}{c}\text { Основні } \\
\text { компетентності в } \\
\text { природничих науках і } \\
\text { технологіях }\end{array}$ & \multicolumn{2}{|c|}{ Не формується } & $\begin{array}{l}\text { Форму- } \\
\text { ється }\end{array}$ & \multicolumn{3}{|c|}{ Не формується } \\
\hline $\begin{array}{l}\text { Інформаційно- } \\
\text { цифрова } \\
\text { компетентність }\end{array}$ & \multicolumn{6}{|c|}{ Формується } \\
\hline $\begin{array}{c}\text { Уміння вчитися } \\
\text { упродовж життя }\end{array}$ & \multicolumn{6}{|c|}{ Формується } \\
\hline $\begin{array}{c}\text { Ініціативність і } \\
\text { підприємливість }\end{array}$ & \multicolumn{6}{|c|}{ Формується } \\
\hline $\begin{array}{c}\text { Соціальна та } \\
\text { громадянська } \\
\text { компетентності }\end{array}$ & \multicolumn{6}{|c|}{ Формується частково } \\
\hline $\begin{array}{c}\text { Обізнаність та } \\
\text { самовираження у } \\
\text { сфері культури }\end{array}$ & \multicolumn{3}{|c|}{ Формується ситуативно } & $\begin{array}{l}\text { Форму- } \\
\text { ється }\end{array}$ & \multicolumn{2}{|c|}{$\begin{array}{l}\text { Формується } \\
\text { ситуативно }\end{array}$} \\
\hline $\begin{array}{c}\text { Екологічна } \\
\text { грамотність і здорове } \\
\text { життя }\end{array}$ & \multicolumn{2}{|c|}{ Не формується } & $\begin{array}{l}\text { Форму- } \\
\text { ється } \\
\text { ситуа- } \\
\text { тивно }\end{array}$ & \multicolumn{3}{|c|}{ Не формується } \\
\hline
\end{tabular}

Як видно зі змісту таблиці 1, ключові компетентності в учнів першого класу на уроках іноземної мови формуються різною мірою.

Компонентами такої ключової компетентності, як спілкування державною (i рідною в разі відмінності) мовами, $є$ вміння використовувати українознавчий компонент у всіх видах мовленнєвої діяльності, засобами іноземної мови популяризувати Україну, українську мову, культуру, традиції. Зазначимо, що їх формування в першому класі відбувається частково, передусім у межах теми ситуативного спілкування “Свята". Застосування державної або рідної мови в процесі навчання іноземних мов зведено до мінімуму, однак наявне під час пояснення завдань, про що свідчить їх двомовне репрезентування в підручниках, значення окремих слів та фраз (здебільшого в словниках, уміщених у чинних підручниках). Зазначимо, що в першому класі, коли учні тільки починають опановувати іноземну мову, державна (або рідна) застосовується більше, ніж у подальших класах.

Формування такої компетентності, як спілкування іноземними є провідною метою навчання, тому можна говорити про системне ії формування відповідно до вікових особливостей учнів. У першому класі вона лише починає формуватися й реалізується, згідно $з$ функційним критерієм, переважно через низку мовленнєвих функцій, як-от: привітатися, 
попрощатися, подякувати, ставити запитання й відповідати на них, виражати настрій тощо. Лексичний діапазон учнів містить слова на позначення членів родини, кольорів, іграшок, днів тижня, домашніх улюбленців, назв свят, шкільного приладдя тощо. Крім того, учні засвоюють числа від 1 до 10, називають вік молодших членів своєї родини, що закладає підгрунтя для формування математичної компетентності.

Математична компетентність в учнів першого класу формується обмежено, оскільки учні можуть використовувати в мовленні лише числівники першого десятка, найбільшою мірою в межах теми “Я, моя родина і друзі”, під час вивчення інших тем - ситуативно. Аналіз змісту чинних підручників для першого класу засвідчує, що автори пропонують значну кількість завдань, які потребують називання кількості предметів, ціну, вік тощо. Крім того, числівники учні застосовують в настільних іграх. 3 огляду на це можна зробити висновок про те, що учнів, згідно з вимогами чинної програми, залучають до “розв' язання комунікативних та навчальних проблем, застосовуючи логіко-математичний інтелект” [4].

Основні компетентності у природничих науках і технологіях формуються відповідно до лексичного й тематичного критеріїв частково, в межах теми “Природа”, оскільки лексичний діапазон, згідно з програмою, містить лише назви тварин-домашніх улюбленців. Першокласники вчаться описувати їх двома-трьома реченнями. Відзначимо, що хоч програма для першого класу й не передбачає таких ситуативних тем, як “Рослини”, “Пори року”, проте в деяких підручниках вони реалізовані. Тож формування означених компетентностей значною мірою залежить від змісту конкретного підручника.

Інформаційно-ииффрова компетентність формується повною мірою під час використання в процесі навчання інформаційних технологій, ігор, що є невід’ємним складником сучасного освітнього процесу. Психологи доводять, що учні, народжені в XXI столітті, звикли користуватися комп'ютерами, ноутбуками, планшетами, смартфонами, тому залучення цих засобів в освітній процес $є$ логічним і доцільним.

Аналіз змісту підручників іноземних мов засвідчив, що всі вони мають аудіопідтримку, яка дає змогу учням сприймати іншомовне мовлення на слух, засвоювати нормативну вимову звуків. Окремі підручники містять покликання (QR-коди) на мультимедійні матеріали в мережі інтернет. Учнів спонукають до читання й написання стислих електронних повідомлень, реалізуючи такі мовленнєві функції, як привітатися, попрощатися, подякувати, представити себе/ когось, ставити запитання й відповідати на них тощо.

Уміння вчитися впродовж життя. У першому класі учні лише починають самостійно працювати з підручником, робочим зошитом, розрізняти систему позначок, що спрямовує їхню навчальну діяльність, привчаються шукати інформацію з різних джерел, а також організовувати свій час і навчальний простір, однак ще не здатні критично оцінювати інформацію та оцінювати власні навчальні досягнення, що зумовлено їхніми віковими особливостями. Попри це, ми можемо стверджувати, що означена компетентність формується.

Така ключова компетентність, як ініиіативність і підприємливість, потребує сформованості вмінь ініціювати усну, писемну, зокрема онлайн-взаємодію іноземною мовою для розв'язання конкретної життєвої ситуації. Як уже зазначалося вище, у першому класі учні оволодівають мовленнєвими етикетними формулами привітання, прощання, вчаться представити себе або когось, описувати когось або щось, привітати зі святом, ставити запитання, тобто оволодівають необхідним мінімумом умінь для ініціювання комунікативної взаємодії іноземною мовою. Отже, ми можемо сказати, що означена компетентність формується з першого класу.

Соціальна та громадянська компетентності формуються частково, оскільки складно говорити про сформованість в учнів першого класу вмінь формулювати власну позицію, водночас вони співпрацюють з іншими суб'єктами освітнього процесу, спілкуючись іноземною мовою (у межах словникового запасу). Результатом такої співпраці є здобування знань з іноземної мови, формування вмінь нею послуговуватися. Відзначимо, що в першому класі відбувається 
соціалізація учнів, оскільки вони звикають до нового колективу, вчаться спілкуватися з незнайомими людьми, що значною мірою забезпечує формування означеної компетентності.

Обізнаність та самовираження у сфері культури потребує сформованого вміння висловлювати іноземною мовою власні почуття, переживання і судження. 3-поміж мовленнєвих функцій, які виокремлює чинна програма для першого класу, наявна така функція, як виражати настрій. 3 огляду на це учні можуть обмежено виражати власні почуття, що зумовлено їхнім недостатнім словниковим запасом. Першокласники, згідно з вимогами чинної програми, ознайомлюються зі святами в Україні та в країні, мова якої вивчається, що сприяє усвідомленню учнями цінності культури для людини й суспільства. Зважаючи на це, можемо стверджувати, що означена компетентність формується.

Згідно зі змістом програми, у першому класі не передбачено формування такої ключової компетентності, як екологічна грамотність $і$ здорове життя. Словниковий запас учнів ще не дозволяє їм повноцінно пропагувати здоровий спосіб життя засобами іноземної мови, до програми не включено мовленнєві функції, необхідні для цього. Водночас передбачено тему ситуативного спілкування “Природа”, однак лексичний діапазон учнів обмежений переважно словами на позначення тварин-домашніх улюбленців. Утім зауважимо, що в деяких підручниках автори включили елементарні відомості про екологію та здоровий спосіб життя, що дозволяє стверджувати про ситуативне формування означеної ключової компетентності відповідно до змісту окремих підручників.

Таблиия 2

Формування ключових компетентностей на уроках іноземної мови в учнів другого класу

\begin{tabular}{|c|c|c|c|c|c|c|c|}
\hline \multicolumn{8}{|c|}{2 клас } \\
\hline & \multicolumn{7}{|c|}{ Тематика ситуативного спілкування } \\
\hline $\begin{array}{c}\text { Ключові } \\
\text { компетентності }\end{array}$ & $\begin{array}{c}\text { Я, моя } \\
\text { родина і } \\
\text { друзі }\end{array}$ & $\begin{array}{c}\text { Відпо- } \\
\text { чинок і } \\
\text { дозвілля }\end{array}$ & Природа & Людина & $\begin{array}{l}\text { Свята та } \\
\text { традиції }\end{array}$ & $\begin{array}{l}\text { Харчу- } \\
\text { вання }\end{array}$ & Школа \\
\hline $\begin{array}{c}\text { Спілкування } \\
\text { державною } \\
\text { (рідною) мовою }\end{array}$ & \multicolumn{7}{|c|}{ Формується частково } \\
\hline $\begin{array}{c}\text { Спілкування } \\
\text { іноземними } \\
\text { мовами }\end{array}$ & \multicolumn{7}{|c|}{ Формується } \\
\hline $\begin{array}{c}\text { Математична } \\
\text { компетентність }\end{array}$ & $\begin{array}{c}\text { Форму- } \\
\text { ється }\end{array}$ & \multicolumn{3}{|c|}{ Формується ситуативно } & \multicolumn{2}{|c|}{ Формується } & $\begin{array}{c}\text { Форму- } \\
\text { ється } \\
\text { ситуа- } \\
\text { тивно }\end{array}$ \\
\hline $\begin{array}{c}\text { Основні } \\
\text { компетентності } \\
\text { в природничих } \\
\text { науках і } \\
\text { технологіях }\end{array}$ & \multicolumn{2}{|c|}{ Не формується } & $\begin{array}{l}\text { Форму- } \\
\text { ється }\end{array}$ & \multicolumn{4}{|c|}{ Не формується } \\
\hline $\begin{array}{c}\text { Інформаційно- } \\
\text { цифрова } \\
\text { компетентність }\end{array}$ & \multicolumn{7}{|c|}{ Формується } \\
\hline $\begin{array}{c}\text { Уміння вчитися } \\
\text { упродовж життя }\end{array}$ & \multicolumn{7}{|c|}{ Формується } \\
\hline $\begin{array}{l}\text { Ініціативність і } \\
\text { підприємливість }\end{array}$ & \multicolumn{7}{|c|}{ Формується } \\
\hline $\begin{array}{c}\text { Соціальна та } \\
\text { громадянська } \\
\text { компетентності }\end{array}$ & \multicolumn{7}{|c|}{ Формується частково } \\
\hline
\end{tabular}


Збірник наукових прац,ь. Випуск 26 (1-2019) Частина 2

\begin{tabular}{|c|c|c|c|c|c|c|c|}
\hline \multicolumn{8}{|c|}{2 клас } \\
\hline & \multicolumn{7}{|c|}{ Тематика ситуативного спілкування } \\
\hline $\begin{array}{c}\text { Ключові } \\
\text { компетентності }\end{array}$ & $\begin{array}{c}\text { Я, моя } \\
\text { родина і } \\
\text { друзі }\end{array}$ & $\begin{array}{c}\text { Відпо- } \\
\text { чинок і } \\
\text { дозвілля }\end{array}$ & Природа & Людина & $\begin{array}{l}\text { Свята та } \\
\text { традиції }\end{array}$ & $\begin{array}{l}\text { Харчу- } \\
\text { вання }\end{array}$ & Школа \\
\hline $\begin{array}{c}\text { Обізнаність та } \\
\text { самовираження у } \\
\text { сфері культури }\end{array}$ & \multicolumn{4}{|c|}{ Формується ситуативно } & $\begin{array}{l}\text { Форму- } \\
\text { єТься }\end{array}$ & \multicolumn{2}{|c|}{$\begin{array}{l}\text { Формується } \\
\text { ситуативно }\end{array}$} \\
\hline $\begin{array}{c}\text { Екологічна } \\
\text { грамотність і } \\
\text { здорове життя }\end{array}$ & \multicolumn{2}{|c|}{ Не формується } & \multicolumn{2}{|c|}{$\begin{array}{l}\text { Формується } \\
\text { ситуативно }\end{array}$} & \multicolumn{3}{|c|}{ Не формується } \\
\hline
\end{tabular}

Формування ключових компетентностей учнів початкової школи в другому класі (Таблиця 2) багато в чому подібне до формування означених компетентностей у першому класі, адже і в першому, і в другому класах іноземна мова вивчається на рівні Pre A1. Як свідчить аналіз змісту програми, учні обох класів засвоюють однаковий набір мовленнєвих функцій. Проте тематику ситуативного спілкування в другому класі доповнює тема “Людина”, розширюється лексичний діапазон. Школярі мають досвід та знання, здобуті в першому класі, що допомагає їм підвищити рівень сформованості ключових компетентностей.

Спілкування державною (рідною) мовою - єдина ключова компетентність, яка в другому класі формується меншою мірою, ніж у першому. Пов’язано це з тим, що в сучасній системі освіти на уроках іноземної мови спілкування має відбуватися саме іноземною мовою для глибшого занурення в іншомовне середовище, державна мова використовується лише в разі потреби. Як уже зазначалося, учні другого класу вже мають певний словниковий запас, здобутий у першому класі, отже, необхідність у використанні державної мови знижується. Проте рівень володіння учнями іноземною мовою в другому класі ще не дозволяє повністю відмовитися від державної мови, а лише скоротити обсяг їі використання.

Спілкування іноземними мовами. Попри те, що мовленнєві функції ситуативного спілкування (привітатися, попрощатися, вибачитися, подякувати, представити себе/когось тощо) однакові для першого та другого класів, тематика ситуативного спілкування й лексичний діапазон розширюються, додається тема Людина", збільшується словниковий запас учнів, оскільки добір лексичного матеріалу здійснюється не тільки з урахуванням вікових особливостей учнів, а й комунікативних завдань. Лексичний матеріал, об'єднаний комунікативною функцією, в освітній процес вводиться поступово, від простого - до складного. Так, наприклад, у першому класі учні ознайомилися з темою “Харчування”, мовний інвентар якої обмежений простим меню, а в другому класі учні засвоюють назви фруктів, овочів, напоїв та ціни на них. Це закладає підгрунтя для формування в учнів умінь використовувати мовні одиниці в різних контекстах відповідно до комунікативних завдань.

Математична компетентність. Якщо в першому класі на уроках іноземної мови учні вивчали числівники від 1 до 10, то в другому - до 20, насамперед у межах тем “Я, моя родина і друзі” (вік молодших членів родини і друзів), “Свята та традиції” (час, години), “Харчування” (ціна фруктів, овочів, напоїв). Як бачимо зі змісту тем, їхній лексичний діапазон передбачає безпосередньо використання числівників в різних комунікативних ситуаціях та застосування логіко-математичного інтелекту, що свідчить про формування математичної компетентності учнів, щоправда, обмежене незначною кількістю засвоєних числівників. У процесі опанування інших тем означена компетентність може формуватися ситуативно (у випадку застосування числівників).

Основні компетентності в природничих науках і технологіях, як і в першому класі, формуються в межах теми ситуативного спілкування "Природа", у процесі засвоєння якої лексичний діапазон розширюється через засвоєння учнями назв диких та свійських тварин, пір року, що дає змогу урізноманітнити тематику спілкування. 
Інформаційно-иифрова компетентність, як і в першому класі, формується шляхом реалізації низки мовленнєвих функцій, наприклад: ставити запитання й відповідати на них, розуміти та виконувати прості вказівки/інструкції/команди, розуміти прості інформаційні знаки тощо. В освітньому процесі системно застосовують інформаційні технології, ігри, медіаресурси. Незалежно від вимог програми щодо використання електронних перекладних словників, додатків для здійснення перекладу, як свідчать спостереження, їх активно застосовують сучасні учні початкових класів.

Уміння вчитися впродовж життя. 3 огляду на те, що в першому класі учні набули певного досвіду користування підручником, робочим зошитом, у них сформовані вміння шукати інформацію з різних джерел, організовувати свій час і навчальний простір, у другому класі вони закріплюють ці вміння. Можна стверджувати, що учні другого класу мають певний досвід самостійної діяльності, що є важливим складником означеної компетентності.

Ініціативність і підприємливість. У другому класі за рахунок розширення лексичного діапазону учні можуть розв'язати більше життєвих ситуацій, ніж у першому класі, вони можуть ставити запитання й відповідати на них, привітати когось зі святом, виражати свій настрій. 3 огляду на це вважаємо, що означена компетентність формується.

Соціальна та громадянська компетентності формуються частково, оскільки учні другого класу продовжують на уроках співпрацювати з іншими суб'єктами освітнього процесу, спілкуючись іноземною мовою, водночас зазначимо, що учні ще не опанували мовленнєві функції для висловлення власної позиції.

Обізнаність та самовираження у сфері культури формується шляхом залучення учнів до нового соціального досвіду, ознайомлення їх зі святами та традиціями України та країни, мову якої вивчають, а також із зарубіжним дитячим фольклором, доступними уривками творів 3 художньої літератури.

Екологічна грамотність і здорове життя. Програмою не передбачено в другому класі формування цієї ключової компетентності. Як і в першому класі, до програми не включено мовленнєві функції, необхідні для пропагування здорового способу життя засобами іноземної мови. Тему ситуативного спілкування "Природа" значно розширено (пори року, дикі та свійські тварини), кім того, введено тему “Людина”, яка передбачає засвоєння іноземною мовою назв частин тіла, що уможливлює ситуативне формування означеної ключової компетентності за умов добору вчителем завдань, спрямованих на пропагування здорового способу життя.

Таблиия 3

Формування ключових компетентностей на уроках іноземної мови в учнів третього класу

\begin{tabular}{|c|c|c|c|c|c|c|c|c|}
\hline \multicolumn{9}{|c|}{3 клас } \\
\hline & \multicolumn{8}{|c|}{ Тематика ситуативного спілкування } \\
\hline $\begin{array}{c}\text { Ключові } \\
\text { компетентності }\end{array}$ & 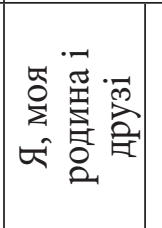 & 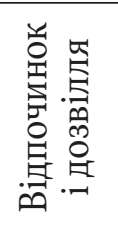 & 䍃 & 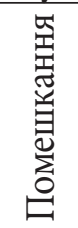 & 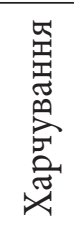 & 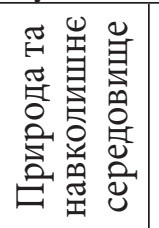 & 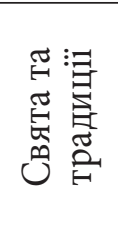 & 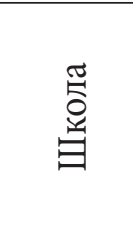 \\
\hline $\begin{array}{c}\text { Спілкування } \\
\text { державною } \\
\text { (рідною) мовою }\end{array}$ & \multicolumn{8}{|c|}{ Формується частково } \\
\hline $\begin{array}{c}\text { Спілкування } \\
\text { іноземними } \\
\text { мовами }\end{array}$ & \multicolumn{8}{|c|}{ Формується } \\
\hline $\begin{array}{c}\text { Математична } \\
\text { компетентність }\end{array}$ & $\begin{array}{l}\text { Форму- } \\
\text { ється }\end{array}$ & \multicolumn{4}{|c|}{ Формується ситуативно } & \multicolumn{2}{|c|}{ Формується } & $\begin{array}{c}\text { Форму- } \\
\text { ється } \\
\text { ситуа- } \\
\text { тивно }\end{array}$ \\
\hline
\end{tabular}




\begin{tabular}{|c|c|c|c|c|c|c|c|c|}
\hline \multicolumn{9}{|c|}{3 клас } \\
\hline & & & емат & иту: & ого с & пкування & & \\
\hline $\begin{array}{c}\text { Ключові } \\
\text { компетентності }\end{array}$ & 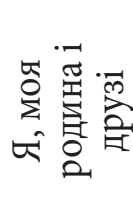 & 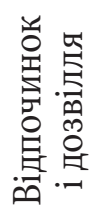 & 絯 & 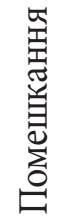 & 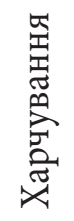 & 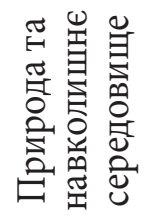 & 突 & 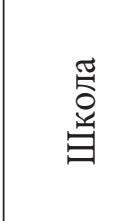 \\
\hline $\begin{array}{c}\text { Основні } \\
\text { компетентності } \\
\text { в природничих } \\
\text { науках і технологіях }\end{array}$ & \multicolumn{5}{|c|}{ Не формується } & $\begin{array}{l}\text { Форму- } \\
\text { ється }\end{array}$ & \multicolumn{2}{|c|}{ Не формується } \\
\hline $\begin{array}{l}\text { Інформаційно- } \\
\text { цифрова } \\
\text { компетентність }\end{array}$ & \multicolumn{8}{|c|}{ Формується } \\
\hline $\begin{array}{c}\text { Уміння вчитися } \\
\text { упродовж життя }\end{array}$ & \multicolumn{8}{|c|}{ Формується } \\
\hline $\begin{array}{c}\text { Ініціативність і } \\
\text { підприємливість }\end{array}$ & \multicolumn{8}{|c|}{ Формується } \\
\hline $\begin{array}{c}\text { Соціальна та } \\
\text { громадянська } \\
\text { компетентності }\end{array}$ & \multicolumn{8}{|c|}{ Формується } \\
\hline $\begin{array}{c}\text { Обізнаність та } \\
\text { самовираження у } \\
\text { сфері культури }\end{array}$ & \multicolumn{6}{|c|}{ Формується ситуативно } & $\begin{array}{l}\text { Форму- } \\
\text { ється }\end{array}$ & $\begin{array}{r}\text { Форму } \\
\text { ється } \\
\text { ситуа- } \\
\text { тивно }\end{array}$ \\
\hline $\begin{array}{c}\text { Екологічна } \\
\text { грамотність і } \\
\text { здорове життя }\end{array}$ & \multicolumn{5}{|c|}{ Не формується } & $\begin{array}{l}\text { Форму- } \\
\text { єТься } \\
\text { ситуа- } \\
\text { тивно }\end{array}$ & \multicolumn{2}{|c|}{ Не формується } \\
\hline
\end{tabular}

У третьому класі (Таблиця 3) розпочинається другий етап навчання в початковій школі протягом 3-4 класів учні опановують іноземну мову на рівні A1. Розширюється тематика ситуативного спілкування, суттєво збагачується лексичний діапазон, мовленнєві функції поповнюються вмінням висловлювати вподобання.

Спілкування державною (рідною) мовою. У третьому класі зменшується обсяг використання української мови на уроках іноземної, водночас розширюється тематика ситуативного спілкування (“Природа та навколишнє середовище України”, “Свята та традиції України”), що уможливлює популяризування України, українських традицій, культури, до того жзбільшення словникового запасу учнів дозволяє розширити межі спілкування.

Спілкування іноземними мовами. Означена компетентність формується впродовж усього освітнього процесу, незалежно від тематики занять та видів завдань. Крім того, що в третьому класі тематика ситуативного спілкування доповнюється новою темою “Помешкання”, що сприяє збагаченню словникового запасу учнів, збільшується й обсяг застосування різних видів мовленнєвої діяльності.

Математична компетентність. У третьому класі учні опановують на уроках іноземної мови числа до 100. Відповідно до вимог програми розширено тематику спілкування в межах знайомих з попередніх класів тем “Я, моя родина і друзі” (вік старших членів родини і друзів), “Свята та традиції” (дата, час). Означена компетентність може формуватися ситуативно і в межах інших тем.

Основні компетентності в природничих науках і технологіях у третьому класі формуються передусім під час вивчення теми “Природа та навколишнє середовище України та країн 
виучуваної мови”. Мовний інвентар школярів розширюється такими елементами, як природні явища, погода та вибір одягу.

Інформаційно-ииффрова компетентність формується, оскільки учні вивчають іноземну мову з використанням програмних засобів, соціальних мереж, адже вони володіють значним досвідом веб-пошуку і часто самостійно знаходять необхідну інформацію з онлайн-джерел, тобто використовують інформаційно-комунікаційні технології для реалізації поставлених завдань.

Уміння вчитися впродовж життя в третьому класі формується системно в процесі навчання іноземної мови.

Ініціативність і підприємливість формується в третьому класі з урахуванням вікових особливостей учнів.

Соціальна та громадянська компетентності формуються, передусім через комунікативну взаємодію з учителем та однокласниками на уроках іноземної мови. Учні третього класу можуть висловлювати вподобання, а отже, формулювати власну позицію іноземною мовою.

Обізнаність та самовираження у сфері культури. Учні розширюють знання про свята та традиції як українські, так і інших країн, мову яких опановують, що сприяє вихованню поваги до багатства й розмаїття культур.

Екологічна грамотність і здорове життя. У третьому класі темою "Природа та навколишнє середовище України та країн виучуваної мови” передбачено розширення лексичного діапазону учнів через вивчення погоди та природних явищ. Це допомагає школярам сприймати природу як цілісну систему, а отже, уможливлює ситуативне формування вищеозначеної ключової компетентності.

Таблиия 4

Формування ключових компетентностей на уроках іноземної мови в учнів четвертого класу

\begin{tabular}{|c|c|c|c|c|c|c|c|c|}
\hline \multicolumn{9}{|c|}{4 клас } \\
\hline & \multicolumn{8}{|c|}{ Тематика ситуативного спілкування } \\
\hline $\begin{array}{c}\text { Ключові } \\
\text { компетентності }\end{array}$ & 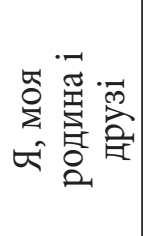 & 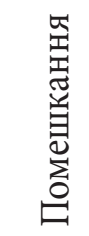 & 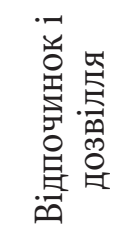 & 茎 & 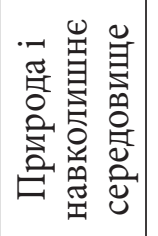 & 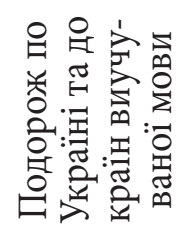 & 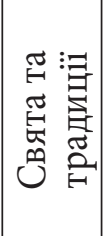 & 惫兽 \\
\hline $\begin{array}{c}\text { Спілкування } \\
\text { державною (рідною) } \\
\text { мовою } \\
\end{array}$ & \multicolumn{8}{|c|}{ Формується частково } \\
\hline $\begin{array}{c}\text { Спілкування } \\
\text { іноземними мовами }\end{array}$ & \multicolumn{8}{|c|}{ Формується } \\
\hline $\begin{array}{c}\text { Математична } \\
\text { компетентність }\end{array}$ & $\begin{array}{l}\text { Форму } \\
\text { ситуат }\end{array}$ & $\begin{array}{l}\text { ETЬСя } \\
\text { ИВНО }\end{array}$ & $\begin{array}{l}\text { Форму- } \\
\text { ється }\end{array}$ & \multicolumn{5}{|c|}{ Формується ситуативно } \\
\hline $\begin{array}{c}\text { Основні } \\
\text { компетентності в } \\
\text { природничих науках і } \\
\text { технологіях } \\
\end{array}$ & \multicolumn{4}{|c|}{ Не формується } & $\begin{array}{c}\text { Форму- } \\
\text { ється }\end{array}$ & \multicolumn{3}{|c|}{ Не формується } \\
\hline $\begin{array}{c}\text { Інформційно-цифрова } \\
\text { компетентність }\end{array}$ & \multicolumn{8}{|c|}{ Формується } \\
\hline $\begin{array}{c}\text { Уміння вчитися } \\
\text { упродовж життя }\end{array}$ & \multicolumn{8}{|c|}{ Формується } \\
\hline $\begin{array}{l}\text { Ініціативність і } \\
\text { підприємливість }\end{array}$ & \multicolumn{8}{|c|}{ Формується } \\
\hline
\end{tabular}




\begin{tabular}{|c|c|c|c|c|c|c|c|c|}
\hline \multicolumn{9}{|c|}{4 клас } \\
\hline & \multicolumn{8}{|c|}{ Тематика ситуативного спілкування } \\
\hline $\begin{array}{c}\text { Ключові } \\
\text { компетентності }\end{array}$ & 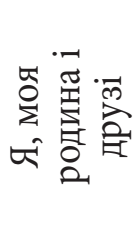 & 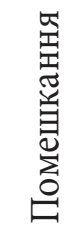 & 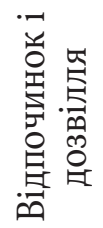 & 焉 & 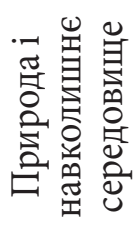 & 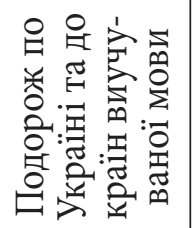 & 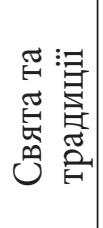 & 总兽 \\
\hline $\begin{array}{c}\text { Соціальна та } \\
\text { громадянська } \\
\text { компетентності }\end{array}$ & \multicolumn{8}{|c|}{ Формується } \\
\hline $\begin{array}{c}\text { Обізнаність та самови- } \\
\text { раження у сфері } \\
\text { культури }\end{array}$ & \multicolumn{5}{|c|}{ Формується ситуативно } & \multicolumn{2}{|c|}{ Формується } & $\begin{array}{l}\text { Форму- } \\
\text { ється } \\
\text { ситуа- } \\
\text { тивно }\end{array}$ \\
\hline $\begin{array}{c}\text { Екологічна } \\
\text { грамотність і здорове } \\
\text { життя }\end{array}$ & \multicolumn{3}{|c|}{ Не формується } & Фор & єеться & \multicolumn{3}{|c|}{ Не формується } \\
\hline
\end{tabular}

Спілкування державною (рідною) мовою. У четвертому класі (Таблиця 4) популяризація України відбувається завдяки змісту тем “Природа і навколишнє середовище України”, “Подорож Україною".

Спілкування іноземними мовами. Програмою передбачено, що по закінченню четвертого класу учні мають оволодіти іноземною мовою на рівні A1, що є ознакою формування цієї ключової компетентності.

Математична компетентність. Тематика ситуативного спілкування передбачає безпосереднє використання числівників у мовленні, лише в межах теми "Відпочинок і дозвілля" (магазини і покупки), однак інші теми можуть включати завдання, які потребують умінь розв’язувати комунікативні та навчальні проблеми, застосовуючи логіко-математичний інтелект. Підсумком опанування іноземною мовою в четвертому класі $є$ розуміння на слух цифр, ціни та часу, оперування категоріями кількості, виконання простих інструкцій, що місять відомості про час, місце, числа, що свідчить про сформованість в учнів означеної компетентності.

Основні компетентності в природничих науках і технологіях у четвертому класі формуються завдяки темі “Природа та навколишнє середовище України та країн виучуваної мови”. Лексичний діапазон учнів доповнюється такими елементами, як природні явища та довкілля.

Інформаційно-иифрова компетентність формується, оскільки учні вільно використовують інформаційно-комунікаційні технології в процесі опанування іноземної мови, вчаться спілкуватися іноземною мовою, дотримуватися правил мережевого етикету.

Уміння вчитися впродовж життя в четвертому класі, як і в третьому, формується системно.

Iніนіативність і підприємливість у четвертому класі формується системно з урахуванням вікових особливостей учнів. Аналіз змісту навчальної програми уможливив висновок про формування означеної компетентності за тематичним, лексичним, функційним критеріями, оскільки тематика ситуативного спілкування, словниковий запас учнів, засвоєні мовленнєві функції забезпечують це повною мірою.

Соціальна та громадянська компетентності формуються, оскільки учні четвертого класу взаємодіють з учителем та однокласниками на уроках іноземної мови, а також можуть висловити власну позицію.

Обізнаність та самовираження у сбері культури. Означена компетентність формується передусім у межах тем “Свята та традиції”, “Подорож Україною та країнами виучуваної мови”. 
У четвертому класі формування ключової компетентності “Екологічна грамотність i здорове життя" має не ситуативний характер, а відбувається повноцінно й системно. Необхідним для цього мовним інвентарем учні оволоділи в процесі вивчення тем “Людина" (гігієна, стан здоров’я) та “Природа і навколишнє середовище України та країн, мови яких вивчаються” (довкілля, природні явища).

У процесі навчання іноземних мов кожна ключова компетентність характеризується певним набором соціально значущих комунікативних умінь; здібностей у різних видах іншомовної діяльності, комунікативної поведінки, формування й удосконалення яких і свідчить про послідовну роботу над формуванням ключових компетентностей учнів, що повинна здійснюватися систематично й послідовно. На нашу думку, формування ключових компетентностей учнів початкових класів у процесі навчання іноземної мови має здійснюватися комплексно, передусім через добір ситуативних завдань, які спонукають до засвоєння мовного матеріалу, соціокультурних реалій, а також сприяють розширенню комунікативного й соціального досвіду учнів.

Отже, формування ключових компетентностей учнів початкових класів - це тривалий багатовекторний процес, що потребує розроблення ефективного методичного інструментарію.

Перспективи подальших досліджень полягають у тому, щоб розробити модель контролю формування ключових компетентностей учнів початкових класів, діагностичні матеріали, спрямовані на визначення рівня розвитку ключових компетентностей учнів початкових класів у процесі навчання іноземної мови.

\section{Список використаних джерел}

1. Бібік Н.М. Контроль та оцінювання навчальних досягнень учнів початкової школи : метод. рек. / кол. авт. : Н. М. Бібік (кер.), О.Я. Савченко, Т.М. Байбара, М.С. Вашуленко та ін. Київ : Почат. шк., 2002. 125 с.

2. Возрастная и педагогическая психология : учебник для студентов пед. ин-тов / В.В. Давыдов, Т.В. Другунова, Л.Б. Ительсон и др.; под ред. А.В. Петровского. 2-е изд. испр. и доп. Москва : Просвещение, 1979. 288 с.

3. Державний стандарт початкової загальної освіти / Практика управління закладом освіти : спецвипуск. Київ, 2012. С. 2-33.

4. Іноземні мови. Навчальна програми для загальноосвітніх спеціалізованих навчальних закладів. 1-4 класи (оновлено). 2018. 50 c. URL: https://mon.gov.ua/storage/app/media/ zagalna\%20serednya.

5. Кремень В.Г. Освіта і наука в Україні - інноваційні аспекти. Стратегія. Реалізація. Результати. Київ : Грамота, 2005. 448 с.

6. Лінгводидактичні засади навчання іноземних мов у закладах вищої педагогічної та загальної середньої освіти : монографія / відп. за вип. М.М. Сідун, Т.К. Полонська. Мукачево : МДУ, 2018. 342 с.

7. Нова українська школа: Концептуальні засади реформування середньої школи / МОН України. К., 2016. 40 с.

8. Редько В.Г. Дидактичні та методичні підходи до конструювання змісту навчання іноземних мов у сучасних 3НЗ на компетентнісних засадах: теорія і практика // Іноземні мови у школах України. 2014. № 4. С. 17-23.

9. Редько В.Г. Лінгводидактичні засади навчання іноземної мови учнів початкової школи: метод. посібн. для вчителів ін. мов. Київ : Генеза, 2007. 136 с.

10. Савченко О.Я. Уміння вчитися як ключова компетентність загальної середньої освіти // Компетентнісний підхід у сучасній освіті: світовий досвід та українські перспективи / за заг. ред. О.В. Овчарук. Київ : К.І.С., 2004. С. 34-45. 
The article based on the analysis of the content of the current curriculum in foreign languages and the synthesis of its results determines the continuity of the formation of the identified key competencies of primary school students in accordance with the general characteristics of situational communication. The criteria of the analysis were thematic, lexical, functional. The thematic criterion reflects the potentialities of the topics of situational communication for the formation of key competencies of elementary school students. The lexical determined the correspondence of vocabulary, which primary school students learn for the formation of key competencies. The functional criterion made it possible to see the possibility of formation of the indicated competencies through a number of speech functions, which are mastered by pupils of grades 1-4. Particular attention is paid to the problem of taking into account in the educational process the psychophysiological features of elementary school students. It has been determined that in the process of learning foreign languages, each key competence is characterized by a certain set of socially meaningful communicative skills; abilities in various kinds of foreign-language activities, communicative behavior, formation and improvement of which testifies to the consistent work on the formation of key competencies of students, which must be carried out systematically and consistently. It has been proved that the formation of key competences of primary school students in the process of teaching a foreign language should be carried out comprehensively, first of all through the selection of situational tasks that lead to the acquisition of language material, socio-cultural realities and also contribute to the broadening of the communicative and social experience of students.

Key words: key competences of elementary school students, curriculum, continuity, psychophysiological features of elementary school students.

\section{ДІЯЛЬНІСТЬ КАФЕДРИ ТЕОРІЇ ТА МЕТОДИК ПОЧАТКОВОЇ ОСВІТИ К-ПНУ іМ. І. ОГІЄНКА ЩОДО ПІДГОТОВКИ ПЕДАГОГА ДО РОБОТИ В УМОВАХ НОВОЇ УКРАЇНСЬКОЇ ШКОЛИ}

\section{ACTIVITY OF THE DEPARTMENT OF THEORY AND METHODS OF PRIMARY EDUCATION OF KAMIANETS-PODILSKYI NATIONAL IVAN OHIENKO UNIVERSITY ON TRAINING TEACHERS TO WORK IN THE CONDITIONS OF NEW UKRAINIAN SCHOOL}

У статті проаналізовано впровадження ідей Нової української школи в освітній процес закладів вищої освіти з метою забезпечення реалізації ключових компетентностей майбутніх педагогів Нової української иколи відповідно до нового Державного стандарту початої освіти; описано заходи з реалізації завдань підготовки в університеті сучасного педагога початкової освіти до роботи в Новій українській школі.

Ключові слова: Концепчія Нової української школи, Державний стандарт початкової освіти, компетентнісний, діяльнісний і особистісно зорієнтований підходи, освітній проиес 3ВО, умови НУШ, кафедра теорії та методик початкової освіти К-ПНУ ім. I. Огієнка.

В умовах інтеграції України до європейської спільноти актуалізується потреба у реформуванні й модернізації системи національної освіти. Першим кроком до створення новітнього освітнього простору стала презентація Концепції Нової української школи, що характеризується масштабністю та радикальністю змін.

(c) Наталія Гудима, 2019 